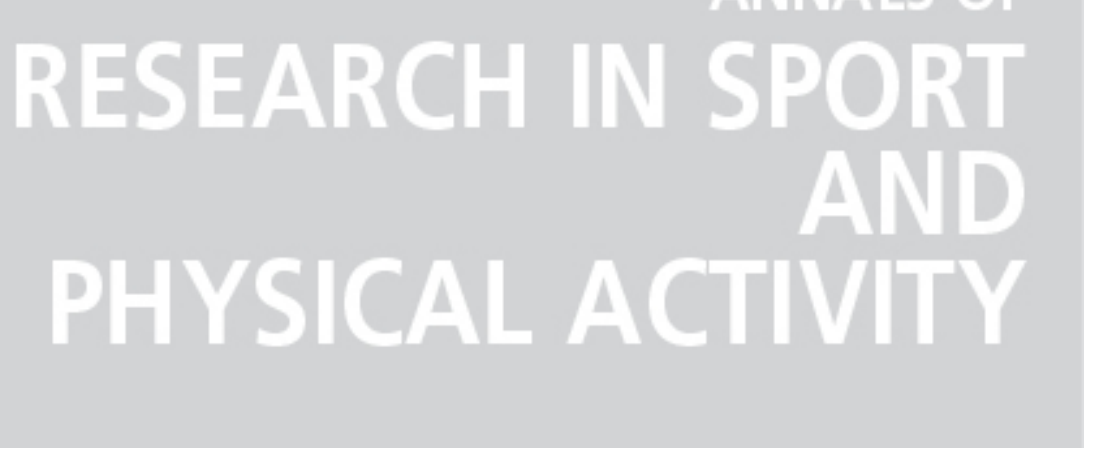

\title{
Age effects in positive outcomes of female volleyball players
}

Autor(es): $\quad$ Santos, Artur J.; Gonçalves, Carlos E.

Publicado por: Imprensa da Universidade de Coimbra

URL

persistente: URI:http://hdl.handle.net/10316.2/28372

DOI: $\quad$ DOl:http://dx.doi.org/10.14195/2182-7087_4_9

Accessed : $\quad$ 26-Apr-2023 10:23:29

A navegação consulta e descarregamento dos títulos inseridos nas Bibliotecas Digitais UC Digitalis, UC Pombalina e UC Impactum, pressupõem a aceitação plena e sem reservas dos Termos e Condições de Uso destas Bibliotecas Digitais, disponíveis em https://digitalis.uc.pt/pt-pt/termos.

Conforme exposto nos referidos Termos e Condições de Uso, o descarregamento de títulos de acesso restrito requer uma licença válida de autorização devendo o utilizador aceder ao(s) documento(s) a partir de um endereço de IP da instituição detentora da supramencionada licença.

Ao utilizador é apenas permitido o descarregamento para uso pessoal, pelo que o emprego do(s) título(s) descarregado(s) para outro fim, designadamente comercial, carece de autorização do respetivo autor ou editor da obra.

Na medida em que todas as obras da UC Digitalis se encontram protegidas pelo Código do Direito de Autor e Direitos Conexos e demais legislação aplicável, toda a cópia, parcial ou total, deste documento, nos casos em que é legalmente admitida, deverá conter ou fazer-se acompanhar por este aviso. 

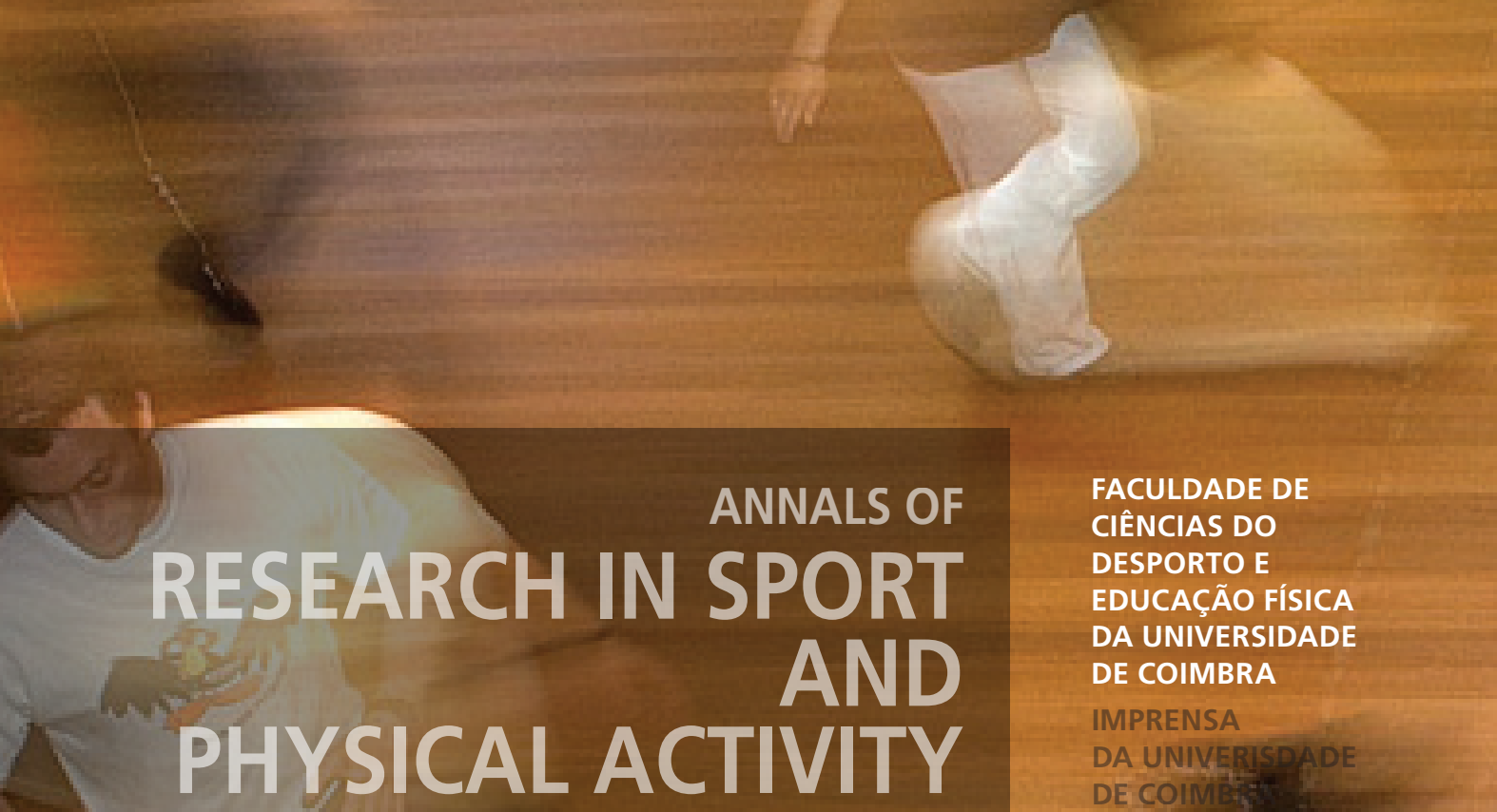
2 • TREINO DESPORTIVO/SPORT TRAINING AGE EFFECTS IN POSITIVE OUTCOMES OF FEMALE VOLLEYBALL PLAYERS 
The bioecological model (Bronfenbrenner, 1999) of human development attributes importance, not only to the individual characteristics but also to contexts. The sport context isn't a closed one, with the athlete carrying experiences and values from other contexts and which can influence the sport experience. The individual and contextual characteristics are important in the youth sport experience from an ecological perspective. This cross-sectional study aims to: a) analyze the age effects in developmental assets, sources of enjoyment and sport attitudes of Portuguese female volleyball players; b) analyze the relation between developmental assets, sources of enjoyment and sport attitudes. The subjects $(n=326)$ were all females aged 12-18 ( $M=14.15, S D=1.09)$ answered to SEYSQ, SAQ and DAP during a tournament. It was performed ANOVA and a Pearson. There were verified differences between age groups in the affiliation with peers. The under 16 presented higher levels of enjoyment than the under 14. It was verified strong correlations between all assets and the sources of enjoyment of positive parental involvement and affiliation with peers. The present study in lights the importance of parents and peers in the positive development and experiences in sport promotion. Due to the important role of coaches and teachers in mediating the behaviors of parents, managers and athletes, they should be aware that promoting a positive development must be a team work with parents and peers involved for the same aim.

Bronfenbrenner, U. (1999). Environments in developmental perspective: Theoretical and operational models. In S. L. Friedman \& T. D. Wachs (Eds.), Measuring Environment Across the Life Span: Emerging Methods and Concepts. pp. 3-28. Washington: American Psychological Association Press.

\footnotetext{
${ }^{1}$ Faculty of Sport Sciences and Physical Education, University of Coimbra, Portugal
} 